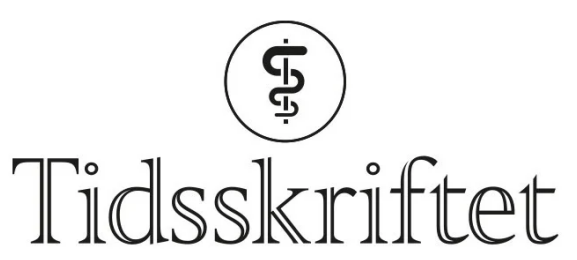

DEN NORSKE LEGEFORENING

\title{
En ung kvinne med pustevansker og proteinuri
}

NOE Å LARE AV

TOR HERVIG

tor.hervig@helse-fonna.no

Klinisk institutt 2

Universitetet i Bergen

og

Laboratorium for immunologi og transfusjonsmedisin

Haugesund sjukehus

Tor Hervig er spesialist i immunologi og transfusjonsmedisin, professor og overlege.

Forfatteren har fylt ut ICMJE-skjemaet og oppgir ingen interessekonflikter.

\section{TOR HENRIK ANDERSON TVEDT}

Medisinsk klinikk

Haukeland universitetssjukehus

og

Avdeling for blodsykdommer

Oslo universitetssykehus, Rikshospitalet

Tor Henrik Anderson Tvedt er ph.d., spesialist i indremedisin og i blodsykdommer og overlege.

Forfatteren har fylt ut ICMJE-skjemaet og oppgir ingen interessekonflikter.

\section{THOMAS KNOOP}

\section{Klinisk institutt 1}

Universitetet i Bergen

og

Medisinsk klinikk

Haukeland universitetssjukehus

Thomas Knoop er spesialist i indremedisin og i nyresykdommer, førsteamanuensis og overlege. Forfatteren har fylt ut ICMJE-skjemaet og oppgir ingen interessekonflikter.

\section{MIRIAM SANDNES}

Det medisinske fakultet

Universitetet i Bergen

Miriam Sandnes er medisinstudent på forskerlinjen.

Forfatteren har fylt ut ICMJE-skjemaet og oppgir ingen interessekonflikter.

\section{HÅKON REIKVAM}

Klinisk institutt 2

Universitetet i Bergen

og

Seksjon for blodsjukdommar 


\section{En kvinne seint i 20-årene ble innlagt med brystsmerter og pustevansker. Utredningen avslørte en komplisert bakgrunn for plagene hennes.}

En tidligere frisk kvinne $i$ slutten av 2o-årene ble innlagt med smerter i høyre del av brystet og pustevansker. Siden hun var på ferie, ble hun innlagt på et annet sykehus enn det hun primcert tilhørte. Dagene før hendelsen følte hun seg slapp og i redusert allmenntilstand. I timene før innleggelse hadde hun økende taledyspné. Pasienten brukte ikke prevensjonsmidler, og det var ingen familicer overhyppighet av venøs tromboembolisme.

Ved undersøkelse i mottak var hun medtatt, normotensiv og lett takykard, med puls 10o-11o slag/min. Ved palpasjon ble det funnet lett forstørrede lymfeknuter i aksillene bilateralt. Hematuri $\left(3^{+}\right)$og proteinuri $\left(3^{+}\right)$ble påvist på urinstiks. Blodprøver tatt ved innkomst er gjengitt $i$ tabell 1 . På grunn av dyspné, ble det umiddelbart tatt CT toraks med pulmonal angiografi, som viste lungeembolier $i$ segmentale og subsegmentale arterier (figur 1). Forhøyet D-dimer, lett leukocytose og forhøyet CRP kunne forklares av lungembolifunnet, mens proteinuri og hematuri tydet mer på annen sykdom med nyreaffeksjon.

\section{Tabell 1}

Laboratorieanalyser ved første innleggelse og etter overføring til universitetssykehus (andre innleggelse).

\begin{tabular}{|c|c|c|c|}
\hline Parameter & $\begin{array}{l}\text { Første } \\
\text { innleggelse }\end{array}$ & Andre innleggelse & seområde \\
\hline Hemoglobin & 12,1 & 6,1 & $11,7-15,3 \mathrm{~g} / \mathrm{dL}$ \\
\hline Leukocytter & 13,3 & 19,7 & $3,5-11,0 \times 10^{9} / \mathrm{L}$ \\
\hline Retikulocytter & - & 0,126 & $0,3-0,10 \times 10^{12} / L$ \\
\hline Kreatinin & 63 & 70 & $45-90 \mu \mathrm{mol} / \mathrm{L}$ \\
\hline Trombocytter & 113 & 139 & $165-387 \times 10^{9} / L$ \\
\hline $\begin{array}{l}\text { Aktivert partiell } \\
\text { tromboplastintid (APTT) }\end{array}$ & 44 & 82 & 30-44 sekunder \\
\hline D-dimer & $1,8-3,5$ & - & $<0,50 \mathrm{mg} / \mathrm{L}$ \\
\hline CRP & 71 & 86 & $<5 \mathrm{mg} / \mathrm{L}$ \\
\hline Haptoglobin & 1,8 & $<0,10$ & $0,40-1,90 \mathrm{~g} / \mathrm{L}$ \\
\hline Bilirubin & 15 & 18 & $<20 \mu \mathrm{mol} / \mathrm{L}$ \\
\hline Laktatdehydrogenase & 264 & 554 & $105-205 \mathrm{U} / \mathrm{L}$ \\
\hline Lupusantikoagulant & - & Positiv & Negativ \\
\hline Anti-kardiolipin-IgG & - & 20,5 & $<20 \mathrm{U} / \mathrm{mL}$ \\
\hline Anti-kardiolipin-IgM & - & 36,4 & $<20 \mathrm{U} / \mathrm{mL}$ \\
\hline Anti- $\beta 2$-glykoprotein-IgM & - & 57,7 & $<20 \mathrm{U} / \mathrm{mL}$ \\
\hline
\end{tabular}




\begin{tabular}{|c|c|c|c|}
\hline Parameter & $\begin{array}{l}\text { Første } \\
\text { innleggelse }\end{array}$ & Andre innleggelse & Referanseområde \\
\hline Anti- $\beta 2$-glykoprotein-IgG & & 67,2 & $<20 \mathrm{U} / \mathrm{mL}$ \\
\hline
\end{tabular}

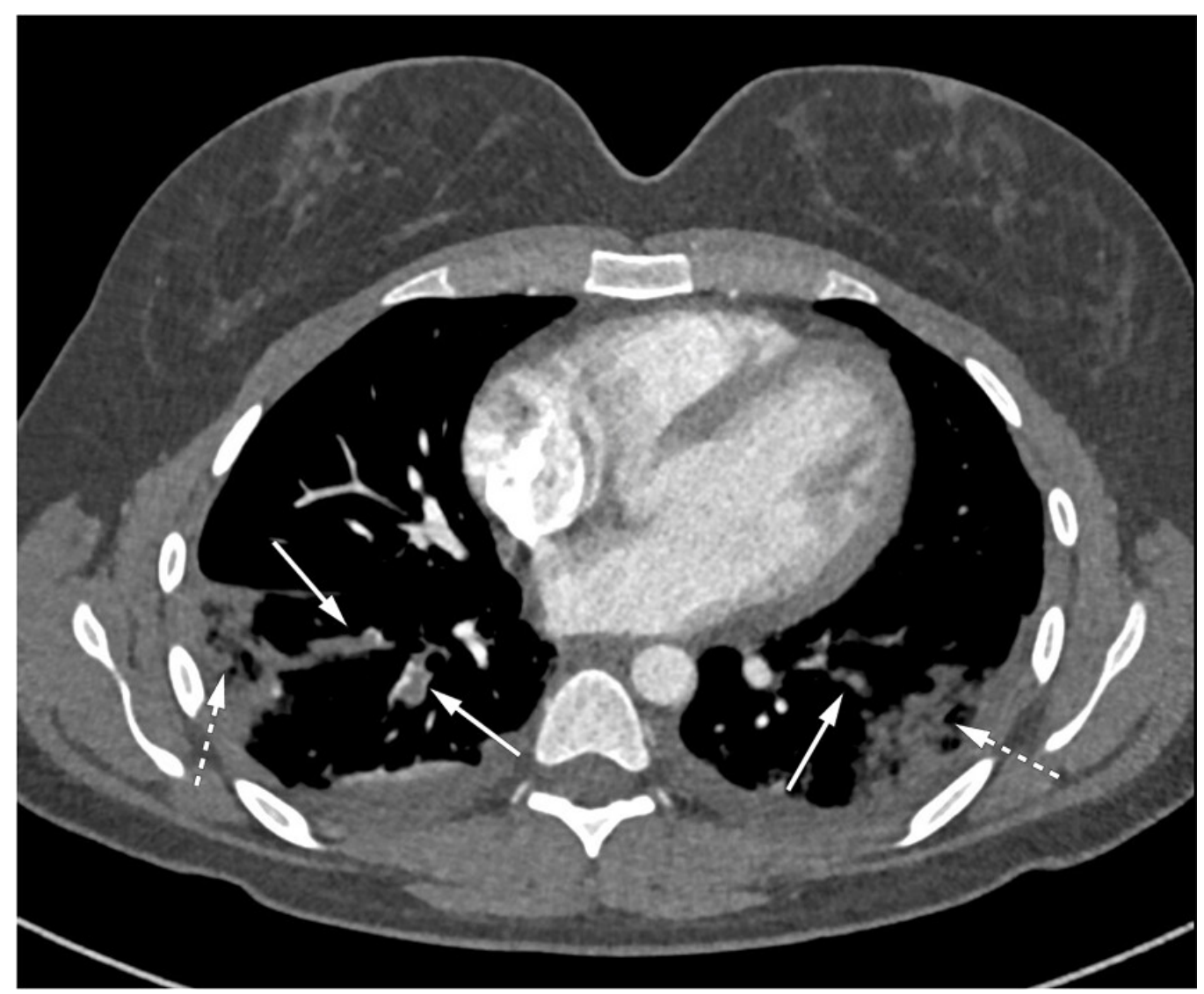

Figur $1 \mathrm{CT}$ thorax med kontrast viser bilaterale lungeembolier (heltrukne piler) og perifere fortetninger forenlig med lungeinfarkt (stiplede piler).

Risikofaktorer for venøs tromboembolisk sykdom inkluderer hereditære årsaker, immobilisering, gjennomgått kirurgi, medikamentell behandling (spesielt bruk av perorale østrogenholdige antikonseptiver) samt malign sykdom. Det foreligger ingen klar anbefaling av hvordan underliggende tilstand bør utredes, men et generelt råd er grundig klinisk undersøkelse, spesielt gynekologisk undersøkelse hos kvinner og prostataundersøkelse hos menn, samt undersøkelse av okkult blod i avføringen.

Trombofiliutredning bør kun gjøres hos yngre pasienter uten kjent utløsende årsak til

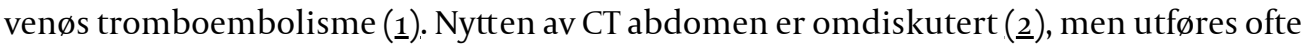
likevel.

Etter funn av lungeembolier på CT ble det startet antikoagulasjonsbehandling med lavmolekylcrt heparin. Prøver for hereditcer trombofili var negative. Over de neste dagene tilkom det et betydelig fall $i$ hemoglobinnivå til 8,1 g/dL (referanseområde 11,7-15,3). Pasienten var klinisk stabil, det var ingen åpenbar blødning fra tarm, og hemofec-test var negativ. Hun ble derfor overført til eget lokalsykehus for videre utredning.

Da hun ankom lokalsykehuset, ble tilstanden oppfattet som forverret. Hun var blek og takykard, med pulsfrekvens $116 \mathrm{slag} / \mathrm{min}$. Blodtrykket var 133/74 $\mathrm{mm} \mathrm{Hg}$, respirasjonsfrekvensen 20 per minutt og $\mathrm{pO}_{2}$ var $97 \%$ (romluft). Hemoglobinnivået hadde falt fra 8,2 $\mathrm{g} / \mathrm{dL}$ til 6,6 $\mathrm{g} / \mathrm{dL}$, og ved kontrollmåling omtrent fire timer etter innleggelsen var hemoglobinnivået 6,o g/dL. Sett mot blodverdiene under første sykehusopphold ga økende laktatdehydrogenase (LD) til $410 \mathrm{U} / \mathrm{L}$ (105-205) samt fallende haptoglobin til o,2 $\mathrm{g} / \mathrm{L}(0,4-2,5)$ mistanke om hemolytisk anemi. Pasientens tilstand ble vurdert som kritisk, og hun ble direkte flyttet til universitetssykehus. 
Ved ankomst var hun medtatt, afebril, med blodtrykk 110/70 mm Hg, puls 113 slag/min, respirasjonsfrekvens 16 per minutt og $\mathrm{pO}_{2} 92 \%$ (uten oksygentilførsel). De viktigste laboratoriefunnene er angitt $i$ tabell 1 . Som ledd $i$ videre utredning ble det utført en direkte antiglobulintest (DAT, også kalt direkte Coombs' test), som var positiv.

Ved direkte antiglobulintest tilsettes antistoff mot immunglobuliner til erytrocytter som er vasket tre ganger. Hvis det er bundet antistoff på overflatene av erytrocytter, vil de agglutinere. Ved monospesifikk direkte antiglobulintest undersøkes det for antistoffer av typen IgG, IgA, IgM eller komplementfaktor ( $\mathrm{C}_{3}$ c eller $\mathrm{C}_{3} \mathrm{~d}$ ) på erytrocyttoverflaten. Ved autoimmun hemolytisk anemi av varmeantistofftype er testen positiv for IgG- eller IgAantistoffer, og ofte positive for IgM og komplementfaktor C3d i tillegg. Ved kuldeagglutininsyndrom er monospesifikk direkte antiglobulintest positiv for IgM og/eller komplementfaktor $\mathrm{C}_{3} \mathrm{~d}$, og det er agglutinering av erytrocytter ved $4{ }^{\circ} \mathrm{C}$.

Direkte antiglobulintest var positiv, men det var også reaksjon i den negative kontrollundersøkelsen, som skal følge oppsettet av testen. Dermed var den opprinnelige utførte testen ikke sikkert tolkbar. Etter innleggelsen fikk pasienten transfusjon med to enheter erytrocyttkonsentrat med god effekt. Allmenntilstanden bedret seg etter dette, og hun ble lettere i pusten. Den videre blodtypeserologiske utredningen viste funn forenlig med autoimmun hemolytisk anemi av varmetype med tilfeldig påvist svakt kuldeantistoffi plasma.

Autoimmun hemolytisk anemi av varmetype er en tilstand der polyklonale antistoffer binder og fører til destruksjon av erytrocytter hovedsakelig i lever og milt. Hos 50-6o \% av pasientene med autoimmun hemolytisk anemi kan man påvise en underliggende sykdom, hos ca. $1 / 3$ en underliggende lavgradig lymfoproliferativ tilstand, f.eks. kronisk lymfatisk leukemi, og hos ca. $1 / 3$ av pasientene en autoimmun sykdom, f.eks. systemisk lupus erythematosus, revmatoid artritt eller ulcerøs kolitt (3).

Hemoglobinstigningen etter transfusjon ble kortvarig. Klinisk var tilstanden relativt uendret de kommende dagene, bortsett fra smerter i høyre flanke, som krevde opiater. Beinmargsundersøkelse viste normal erytropoese og myelopoese, men mindre aktivitet enn forventet ved så uttalt hemolyse. Lymfoproliferativ tilstand kunne ikke påvises.

Det ble startet behandling med prednisolon $80 \mathrm{mg}$ daglig. Av øvrige prøver var leukocytter 19,8× ${ }_{10}^{9} / \mathrm{L}$ og CRP $8 \mathrm{mg} / \mathrm{L}$. På bakgrunn av lav albuminkonsentrasjon (19 $\mathrm{g} / \mathrm{L}$ )og uttalt proteinuri med protein-kreatinin-ratio på $850 \mathrm{mg} / \mathrm{mmoL}$ (anslagsvis $8,5 \mathrm{~g} / \mathrm{d} ø \mathrm{gn}$ ) ble nefrotisk syndrom påvist. Nyrebiopsi var planlagt, men var kontraindisert på grunn av blødningsrisiko under pågående antikoagulasjonsbehandling. I tillegg til vanlige blodprøver ble det tatt prøver med tanke på underliggende autoimmun bindevevssykdom. Trombofiliprøver, som også var tatt ved primarinnleggelse, ble gjentatt og var negative.

Klinisk ble pasienten undersøkt med tanke på malignitet. CT-undersøkelse av toraks og abdomen påviste de kjente lungeemboliene, men viste ingen tegn til nyrevenetrombose eller andre tromboser. Det ble ikke påvist forandringer i noen organer som ga mistanke om malignitet. Mammografi gav ingen holdepunkt for tumor. Gynekologisk undersøkelse viste normale funn.

Etter syv døgn i sykehuset kom det svar som viste positiv lupusantikoagulant samt positive funn av IgG- og IgM-antistoffer mot kardiolipin og $\beta 2$-glykoprotein. Dette kalles «trippelpositiv test» og er assosiert med betydelig økt tromboserisiko. Det er vist at disse pasientene også har antistoff mot fosfatidylserin/protrombin-kompleks (4). Screeningtest for antinuklecere antistoffer var positiv, med autoantistoffer mot kromatin.

Systemisk lupus erythematosus er en autoimmun bindevevssykdom karakterisert ved tilstedeværelse av antinukleære antistoffer. Sykdommen har et bredt spekter av symptomer, inkludert typisk hudutslett i ansiktet og på soleksponerte områder, steril serositt (perikarditt, pleuritt), ikke-destruktiv artritt, nefritt, trombocytopeni, autoimmun hemolytisk anemi og cerebrale symptomer med f.eks. kramper, hodepine og nevropati.

Om lag $40 \%$ av pasientene med lupus har betydelig tromboserisiko grunnet antifosfolipidsyndrom (4). Omvendt har $18 \%$ av pasientene med antifosfolipidsyndrom også systemisk lupus erythematosus (5). Det er vanlig å stille diagnosen basert på 
skåringssystemet til European League Against Rheumatism/American College of Rheumatology (tabell 2) (ㅁ).

\section{Tabell 2}

Diagnostisk skåringssystem for systemisk lupus erythematosus (SLE) fra European League Against Rheumatism / American College of Rheumatology (6). Minimum 10 poeng kreves for å stille diagnosen.

\begin{tabular}{|c|c|c|c|}
\hline Område & Parameter & Poeng & Aktuell pasient \\
\hline $\begin{array}{l}\text { Konstitusjonelle } \\
\text { symptomer }\end{array}$ & Feber & 2 & 2 \\
\hline \multirow[t]{3}{*}{ Hematologi } & Leukopeni & 3 & 0 \\
\hline & Trombocytopeni & 4 & 4 \\
\hline & Autoimmun hemolyse & 4 & 4 \\
\hline \multirow[t]{3}{*}{ Sentralnervesystemet } & Delirium & 2 & 0 \\
\hline & Psykose & 3 & 0 \\
\hline & Anfall & 5 & 0 \\
\hline \multirow[t]{4}{*}{ Hud } & Alopesi & 2 & 0 \\
\hline & Orale ulcerasjoner & 2 & 0 \\
\hline & Diskoid lupus & 4 & 0 \\
\hline & Akutt kutan lupus & 6 & 0 \\
\hline Ledd & Synovitt/tendinitt i to ledd & 6 & 0 \\
\hline \multirow[t]{2}{*}{ Serositt } & Pleural/perikardial væske & 5 & 0 \\
\hline & Akutt perikarditt & 6 & 0 \\
\hline \multirow[t]{3}{*}{ Nyre } & Proteinuri $>0,5 \mathrm{~g} / 24 \mathrm{t}$ & 4 & 4 \\
\hline & Nefritt klasse II eller V & 8 & 0 \\
\hline & Nefritt klasse III eller IV & 10 & 0 \\
\hline Antifosfoslipider & $\begin{array}{l}\text { Antikardiolipin eller Anti- } \beta 2 \text { - } \\
\text { glykoprotein }\end{array}$ & 2 & 2 \\
\hline \multirow[t]{2}{*}{ Komplementfaktorer } & Lav C3 eller C4 & 3 & 0 \\
\hline & Lav C3 og C4 & 4 & 0 \\
\hline \multirow[t]{2}{*}{ Antistoffer } & Anti-dsDNA-antistoff & 6 & 0 \\
\hline & Anti-Smith-antistoff & 6 & 0 \\
\hline
\end{tabular}

I det diagnostiske skåringssystemet fikk pasienten en poengsum på 16, som er tilstrekkelig for systemisk lupus erythematosus ( tabell 2). Det ble konkludert med at pasienten sannsynligvis hadde systemisk lupus erythematosus med sekundcert antifosfolipidsyndrom, sekundcer hemolytisk anemi og nefrotisk syndrom med lav albumin $(<20 \mathrm{~g} / \mathrm{L})$, selv om det ikke forela hudforandringer, leddaffeksjon eller cerebral påvirkning. Nyrebiopsi ville kunne gitt ytterligere diagnostisk verifisering av diagnosen, men var kontraindisert grunnet antikoagulasjonsbehandling. 
Pasienten ble overflyttet til revmatologisk avdeling, og behandling med mykofenolsyre og hydroksyklorokinin ble igangsatt. MR caput og ekkoundersøkelse av hjertet viste ikke tegn til affeksjon av disse organene. Det ble startet behandling med angiotensin II-reseptorblokkeren valsartan for å redusere proteinurien og statinbehandling for hyperkolesterolemi sekundcert til nefrotisk syndrom. Antikoagulasjonsbehandling ble videreført med warfarin. Pasientens tilstand ble gradvis bedre, og hun ble utskrevet 17 dager etter innleggelsen med diagnosene hemolytisk anemi av varmeantistofftype og systemisk lupus erythematosus med sannsynlig lupusnefritt og trippelpositivt antifosfolipidantistoff.

\section{Diskusjon}

Kasuistikken viser en kompleks sykehistorie med uspesifikke symptomer innledningsvis. Initial tentativ diagnose var lungeembolisme. Diagnosen ble raskt bekreftet, og adekvat behandling ble iverksatt.

Hos unge pasienter må man grundig utrede mulige årsaker til lungeembolisme $(7, \underline{8})$. Nefrotisk syndrom gir $\emptyset \mathrm{kt}$ risiko for tromboembolisk sykdom (9.). Årsaken er uklar, men har antagelig med reduserte nivåer av antitrombin, protein $\mathrm{S}$ og plasmin å gjøre. Hos pasienter med nefrotisk syndrom anbefales antikoagulasjonsbehandling med warfarin, da effekten av nye perorale antikoagulerende legemidler og lavmolekylære hepariner er usikker (므). Livslang warfarinbehandling kan være indisert ved antifosfolipidsyndrom.

Få dager ut i sykdomsforløpet utviklet hun en anemi uten kjent blødning. Hemolytisk anemi er kjennetegnet ved forhøyede nivåer av bilirubin, retikulocytter og laktatdehydrogenase og nedsatt haptoglobin. Men som i dette tilfellet, må ikke alle fire funnene være til stede. Den tentative diagnosen autoimmun hemolytisk anemi ble styrket da hemoglobinkonsentrasjonen igjen falt få dager etter transfusjon. Direkte antiglobulintest er positiv hos de fleste med autoimmun hemolytisk anemi, men en liten andel av pasientene har negativ eller kun svak positiv test. En sannsynlig årsak kan være at antistoffer på overflaten til erytrocyttene er maskert og ikke detekteres i analysen.

Vår pasient hadde også påvisbare kuldeagglutininer, og man kunne derfor mistenke at pasienten hadde autoimmun hemolytisk anemi utløst av kuldeagglutininer. Klinisk kuldeagglutininsykdom er sjelden, med en insidens på ca. 2 per 100 ooo (11). Den blodtypeserologiske utredningen ble forstyrret av såkalt "pengerulldannelse» (rouleaux), som førte til uspesifikke reaksjoner. Videre undersøkelser måtte derfor utføres før man kunne konkludere med at pasienten hadde autoimmun hemolytisk anemi av varmetype med tilfeldig påviste kuldeagglutininer uten klinisk betydning.

Hos ca. $40 \%$ av pasienter med autoimmun hemolytisk anemi påvises ingen underliggende sykdom, mens man hos resten finner enten en lymfoproliferativ tilstand, infeksjon, systemisk bindevevssykdom eller malign sykdom (3). Systemisk bindevevssykdom var tentativ diagnose hos vår pasient, ikke minst fordi testen for antinukleære antistoffer var sterkt positiv. Pasienten hadde videre positiv lupusantikoagulant og var positiv for IgG- og IgM-antistoffer mot kardiolipin og $\beta 2$-glykoprotein.

Testen for lupusantikoagulant kan påvirkes av pågående antikoagulasjonsbehandling og skal gjentas etter tre måneder sammen med testing for antifosfolipidantistoffer (1ㅡ). Dette diagnostiske kriteriet for antifosfolipidsyndrom var derfor ikke til stede, men diagnosen fremsto likevel som sannsynlig gitt den kliniske presentasjonen og typiske laboratoriefunn. Antifosfolipidsyndrom kunne ikke forklare det nefrotiske syndromet og heller ikke tilstedeværelse av antinukleære antistoffer. Systemisk lupus erythematosus ble dermed en sannsynlig diagnose.

For vår pasient bidro hemolytisk anemi, nefrotisk syndrom og antifosfolipidantistoffer alle til å gi pasienten stor hyperkoagulabilitet. Systemisk lupus erythematosus og antifosfolipidsyndrom følges ofte ad, og vi finner det overveiende sannsynlig at vår pasient hadde systemisk lupus erythematosus med ledsagende antifosfolipidsyndrom. Primært 
antifosfolipidsyndrom med ledsagende systemisk lupus erythematosus er mindre sannsynlig, siden det ikke tidligere hadde vært symptomer forenlig med antifosfolipidsyndrom (14).

I ettertid er funnene av antifosfolipidantistoffer bekreftet, og funn ved nyrebiopsi har bekreftet diagnosen lupusnefritt.

Pasienten har gitt samtykke til at artikkelen blir publisert.

Takk til overlege Nils Vetti, Radiologisk avdeling, Haukeland universitetssjukehus for bidrag til artikkelen.

Artikkelen er fagfellevurdert.

\section{LITTERATUR}

1. Connors JM. Thrombophilia testing and venous thrombosis. N Engl J Med 2017;377:1177-87. [PubMed][CrossRef]

2. Carrier M, Lazo-Langner A, Shivakumar S et al. Screening for occult cancer in unprovoked venous thromboembolism. N Engl J Med 2015; 373: 697-704. [PubMed][CrossRef]

3. Jäger U, Barcellini W, Broome CM et al. Diagnosis and treatment of autoimmune hemolytic anemia in adults: Recommendations from the First International Consensus Meeting. Blood Rev 2020; 41: 100648. [PubMed][CrossRef]

4. Cattini MG, Bison E, Pontara E et al. Tetra positive thrombotic antiphospholipid syndrome: Major contribution of anti-phosphatidyl-serine/prothrombin antibodies to lupus anticoagulant activity. J Thromb Haemost 2020; 18: 1124-32. [PubMed][CrossRef]

5. Duarte-García A, Pham MM, Crowson CS et al. The Epidemiology of antiphospholipid syndrome: A population-based study. Arthritis Rheumatol 2019; 71: 1545-52. [PubMed][CrossRef]

6. Aringer M, Costenbader K, Daikh D et al. 2019 European League Against Rheumatism/American College of Rheumatology Classification Criteria for Systemic Lupus Erythematosus. Arthritis Rheumatol 2019; 71:1400-12. [PubMed][CrossRef]

7. Heit JA, Spencer FA, White RH. The epidemiology of venous thromboembolism. J Thromb Thrombolysis 2016; 41:3-14. [PubMed][CrossRef]

8. Martinelli I. Thromboembolism in women. Semin Thromb Hemost 2006; 32: 709-15. [PubMed] [CrossRef]

9. Kelddal S, Nykjær KM, Gregersen JW et al. Prophylactic anticoagulation in nephrotic syndrome prevents thromboembolic complications. BMC Nephrol 2019; 20: 139. [PubMed][CrossRef]

10. Ordi-Ros J, Sáez-Comet L, Pérez-Conesa M et al. Rivaroxaban versus vitamin K antagonist in antiphospholipid syndrome: A randomized noninferiority trial. Ann Intern Med 2019; 171: 685-94. [PubMed][CrossRef]

11. Berentsen S, Barcellini W, D'Sa S et al. Cold agglutinin disease revisited: a multinational, observational study of 232 patients. Blood 2020; 136: 480-8. [PubMed][CrossRef]

12. Cohen H, Mackie IJ, Devreese KMI. Clinical and laboratory practice for lupus anticoagulant testing: An International Society of Thrombosis and Haemostasis Scientific and Standardization Committee survey. J Thromb Haemost 2019; 17: 1715-32. [PubMed][CrossRef]

13. Pisetsky DS. Evolving story of autoantibodies in systemic lupus erythematosus. J Autoimmun 2020; 110: 102356. [PubMed][CrossRef]

14. Paule R, Morel N, Le Guern V et al. Classification of primary antiphospholipid syndrome as systemic lupus erythematosus: Analysis of a cohort of 214 patients. Autoimmun Rev 2018; 17: 866-72. [PubMed][CrossRef]

Publisert: 8. november 2021. Tidsskr Nor Legeforen. DOI: 10.4045/tidsskr.21.0171

Mottatt 1.3.2021, første revisjon innsendt 28.5.2021, godkjent 17.8.2021.

Publisert under åpen tilgang CC BY-ND. Lastet ned fra tidsskriftet.no 26. april 2023. 